\title{
INVESTIGATION OF MORPHOLOGICAL CHANGE AT THE CUA DAI RIVER MOUTH THROUGH SATELLITE IMAGE ANALYSIS
}

\begin{abstract}
Hitoshi Tanaka ${ }^{1}$, Vo Cong Hoang ${ }^{2}$ and Nguyen Trung Viet ${ }^{3}$
Morphology of Cua Dai River mouth and adjacent sandy beaches in Hoi An City, Vietnam has been being eroded severely in recent years. Based on analysis of Landsat images, the long-term evolution, decadal scale, of morphology at this area since 1975 to 2015 is discussed. Morphology of river mouth in the period from 1975 to 1991 is highly similar to one in the period from 2003 to 2015, long sandspit on the left side and cuspate shoreline (cuspate foreland) on the right side, whereas the formation of double sandspit and welding between them after that was observed in the period from 1995 to 2002 . From the characteristics of morphological change, there are three types of river mouth formed during the 40-year long period are classified. In addition, results of image analysis also indicate that the right bank of river shifted southward about $250 \mathrm{~m}$. This is corresponding to the period with elongation of sandspit on the left after welding from offshore sandbar. The tip of cuspate shoreline on the right side was also observed to move to the south during the period that right river bank shifting southward. Besides the reduction of sediment supply to the river mouth, the shifting to south of main river channel diverting more sediment deposit on the right side of the river mouth, resulting in the erosion of the Cua Dai Beach on the left side became more serious. Countermeasure, which diverts more sediment to the left side, is highly required. Detailed effectiveness and magnitude of this structure can be evaluated based on numerical simulation.
\end{abstract}

Keywords: Cua Dai River mouth, Thu Bon River, Long-term morphological change, Landsat image, Erosion, River mouth terrace

\section{INTRODUCTION}

Along approximately $3260 \mathrm{~km}$ of Vietnam's coastline, there numbers of river mouths pour into the Pacific Ocean. The evolution of estuarine and coastal morphology highly impacts on the socialeconomics development. In recent years, erosion of river mouth and adjacent coasts became very severe. There have been studies dealing with this problem. Hoang et al. (2015a) investigated the erosion of river mouth and adjacent beaches at the Da Rang River mouth in Tuy Hoa City, south central Vietnam. An area of $7 \mathrm{~km}$ in length has been eroded severely since around 2007. The erosion area is limited in a particular region, the demarcations of which can be obviously obtained from extracted shoreline position data. The role of sand terrace formed in front of river mouth as a submerged sand source was also pointed out. Duc et al. (2012) documented physical mechanism of the erosion at the estuary areas of Red River system, northern Vietnam. Also at this area, Hung and Larson (2014) gave detailed analysis on the coastline and river mouth evolution. Another place also subjected to severe erosion is the Cua Dai River mouth and adjacent beaches in Hoi An City, central Vietnam. About $200 \mathrm{~m}$ width of sandy beach was eroded in the past ten years. Viet et al. (2015) reported severe erosion of this area through analysis of satellite images. They also proposed the potential erosion mechanism which is attributed to sand mining at the river mouth area. In connection with that, Hoang et al. (2015b) proposed analytical model to simulate the formation of Cua Dai River mouth delta, and the effect of reduction sediment supply from river. On the other hand, one of common challenges faced when carrying out research in Vietnam is the limitation of field data such as bathymetry and wave. In order to cope with that situation, in the field of morphological change study, Hoang et al. (2015a, 2015b); Thanh et al. (2015); and Noshi et al. (2015) utilized satellite images or time-averaged images from video camera monitoring system to investigate the change of estuarine and coastal morphology. However, by utilizing such kind of images, only short-term shoreline evolution can be discussed. In this study, the Landsat images, which have been capturing over a long period from 1975 to 2015, to discuss the long-term morphological evolution of the Cua Dai River mouth.

\section{STUDY AREA AND DATA COLLECTION}

This study focuses on Cua Dai River mouth which is located in the Hoi An City, Quang Nam Province, Vietnam. The location map of study area is presented in Figure 1. Cua Dai is known as river

\footnotetext{
${ }^{1}$ Department of Civil Engineering, Tohoku University, 6-6-06 Aoba, Sendai 980-8579, Japan

2 Department of Hydraulic Structure, Thuyloi University-Southern Campus, 02 Truong Sa, Ward 17, Binh Thanh District, HCM City, Vietnam

${ }^{3}$ Department of Civil Engineering, Thuyloi University, 175 Tay Son, Dong Da District, Hanoi, Vietnam
} 
mouth of Thu Bon River which originates from the west mountainous of the province. The river has the length of $152 \mathrm{~km}$, the basin area of $4100 \mathrm{~km}^{2}$, the average annual discharge of $327 \mathrm{~m}^{3} / \mathrm{s}$.

Satellite images (Landsat image), which are used in this study, were acquired from U.S. Geological Survey (USGS) database. These images have been taking over a long period from 1975 to 2015. Resolution of this kind of images is $30 \mathrm{~m}$. In addition, high-resolution satellite images acquired from Google Earth are also utilized in this study. These images cover the period from 2004 to 2015 (5 images). All obtained images are already rectified to the WGS-84 (World Geodetic System - 84). A line with a 140 degree clockwise north direction is taken as a baseline for shoreline position measurement in this area. Detected shoreline positions, wet-dry line, are extracted from rectified satellite images in direction along the beach based on the difference of color intensity of water and land sides. It is noted that all shoreline positions are not corrected to tidal level due to the lack of exact time of capture.

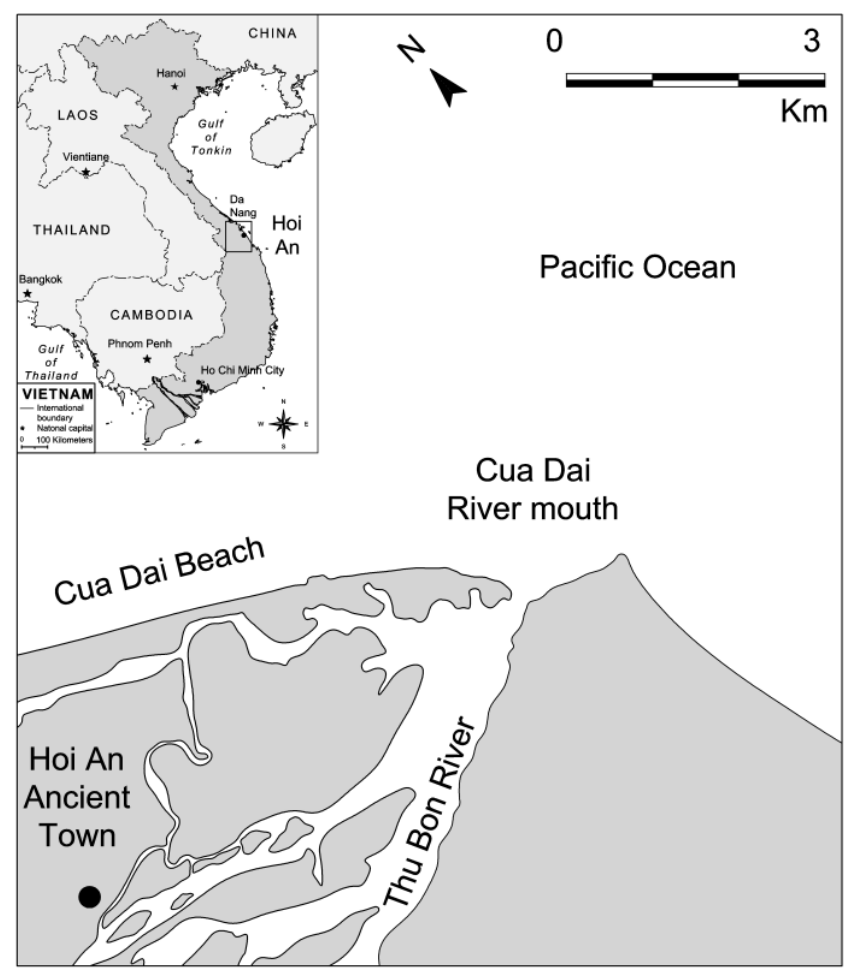

Figure 1. Location map of study area

The $30 \mathrm{~m}$ spatial resolution of Landsat images is too coarse to reveal all detailed changes of shoreline. The level of accuracy of shoreline extraction would always be worse than the $30 \mathrm{~m}$ resolution of the original images. However, that could be applicable for cases which have remarkable changes of magnitude such as river delta or river mouth (Pardo-Pascual et al., 2012). Several techniques to rectify and extract shoreline position from Landsat images and associated uncertainties can be found in Feyisaa et al. (2014); Maiti and Bhattacharya (2009); Pardo-Pascual et al. (2012) and Ryu et al. (2002). While, the technique and relevant uncertainties when extract shoreline position from high-resolution aerial photographs can be found from Pradjoko and Tanaka (2010).

\section{RESULTS AND DISCUSSIONS}

\section{Estuarine morphology changes in the past decades}

The long-term evolution of morphology at the Cua Dai River mouth is discussed based on acquired Landsat images. By considering the geographical features obtained from image analysis, the entire period is divided into three sub-periods, (i) Period 1 - From 1975 to 1991; (ii) Period 2 - From 1995 to 2002; (iii) Period 3 - From 2003 to 2015, for more detailed discussion on the evolution of morphology. 


\section{Evolution of estuarine morphology in the Period 1 - From 1975 to 1991}

Figure 2 shows selected Landsat images of the Cua Dai River mouth in the Period 1. Estuarine morphology in this period is highly similar to one in the Period 3 which will be presented later. Image taken in 1975 indicates asymmetry morphology between the left and the right of the river mouth. There were long sandspit on the left and cuspate shoreline (cuspate foreland) on the right. The river mouth was rather narrow at this time. The next image (1989) shows that apart of sandspit on the left side were eroded; the river mouth was wider comparing to the one in 1975. Moreover, the cuspate shoreline on the right side was elongated, and its tip tends to move leftwards. It is interesting that an offshore sandbar was formed in front of the river mouth. It is expected that it was formed by huge amount of sediment supplied by large flood event. After some time (1990), the left side of this sandbar has attached with the shoreline (Sandspit A, Figure 3). Meanwhile, the cuspate shoreline on the right was keeping its form. It can be seen from the image taken in 1991 that Sandspit B (sandbar after attaching with shoreline) still remained and the cuspate shoreline on the right got bigger. In addition, extracted shoreline positions at the Cua Dai River mouth in the Period 1 (Figure 3) are also included to reveal more details on the evolution of morphology in this period.
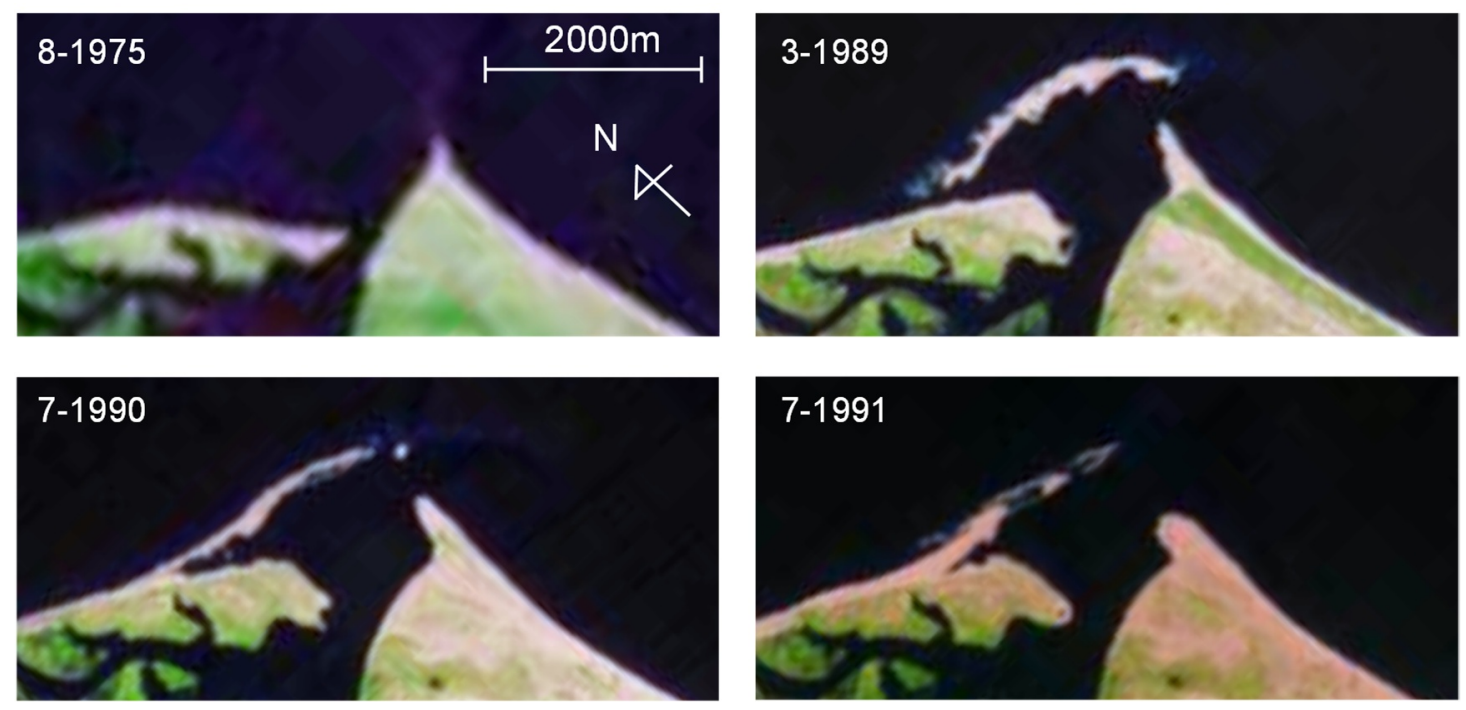

Figure 2. Satellite images of the Cua Dai River mouth in the Period 1 (images courtesy of the U.S. Geological Survey, USGS)

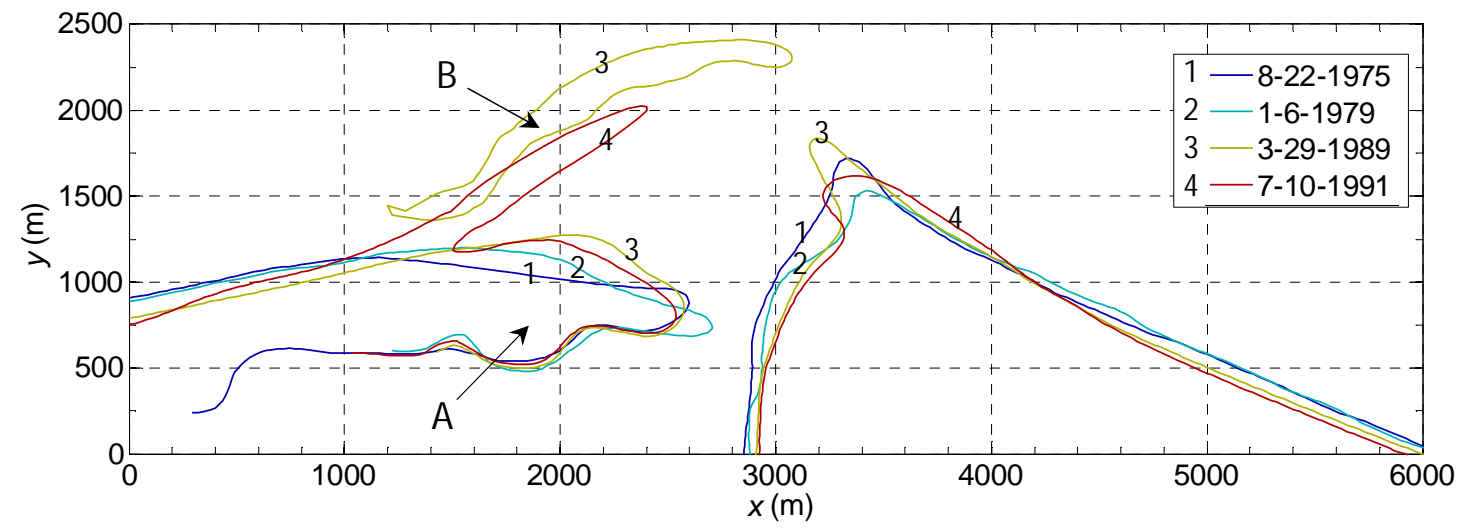

Figure 3. Detected shoreline positions of the Cua Dai River mouth in the Period 1

\section{Evolution of estuarine morphology in the Period 2 - From 1995 to 2002}

The image taken in the beginning of this period (1995, Figure 4) presents existing of double sandspit (A and B). The cuspate shoreline on the right side also turned to the shape of sandspit. Hence, 
there were 3 sandspits at the river mouth at that moment. This also can be similarly observed on image taken in 1996. However, a bit change in the 1996's image is that the Sandspit B was tending to move onshore. The moving of the Sandspit B on the left side is revealed more clearly on the image taken in 2000. At that time, the right tip of Sandspit B attached with the Sandspit A. This phenomenon is well known as the welding between two sandspits (e.g., Robin et al., 2009). On the contrary, the sandspit on the right side was flushed, cuspate shoreline was formed again. The 2002's image shows the higher level of welding of two sandspits on the left side and the more offshore elongated of cuspate shoreline on the right side. The formation of two sandspits at the river mouth, the welding between two sandspits on the left side and the re-formation of cuspate shoreline on the right side can be seen clearly in Figure 5 which illustrates extracted shoreline positions of the river mouth in the Period 2. In addition, it also shows the shifting to the south of river bank on the right side. Maximum shifted distance attained to $200 \mathrm{~m}$ (from 1995 to 2002).
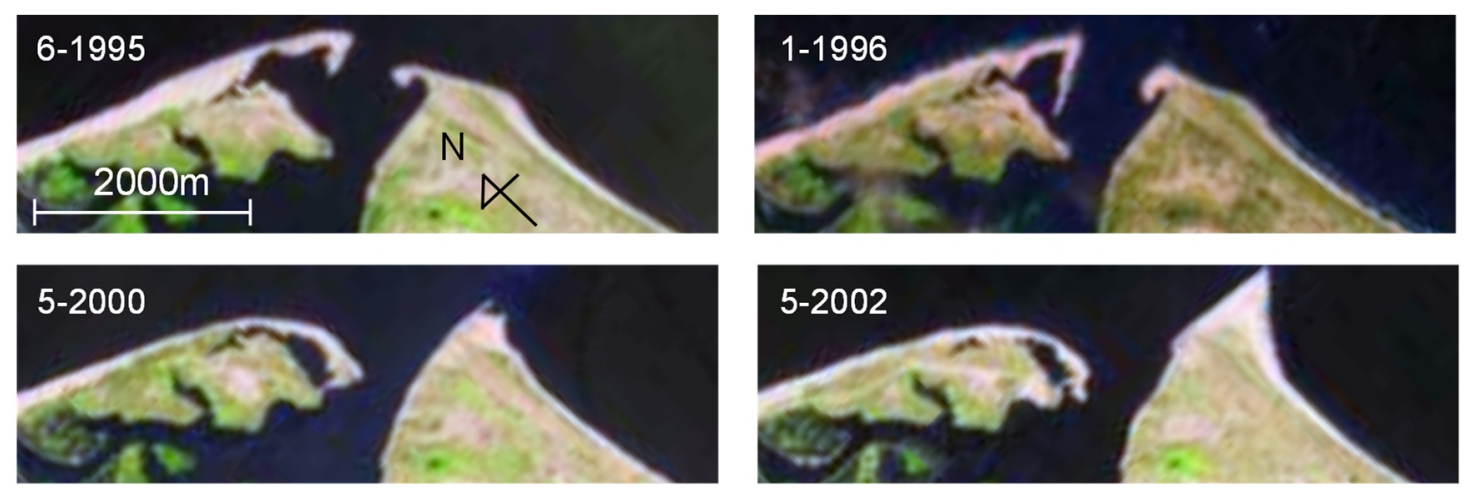

Figure 4. Satellite images of the Cua Dai River mouth in the Period 2

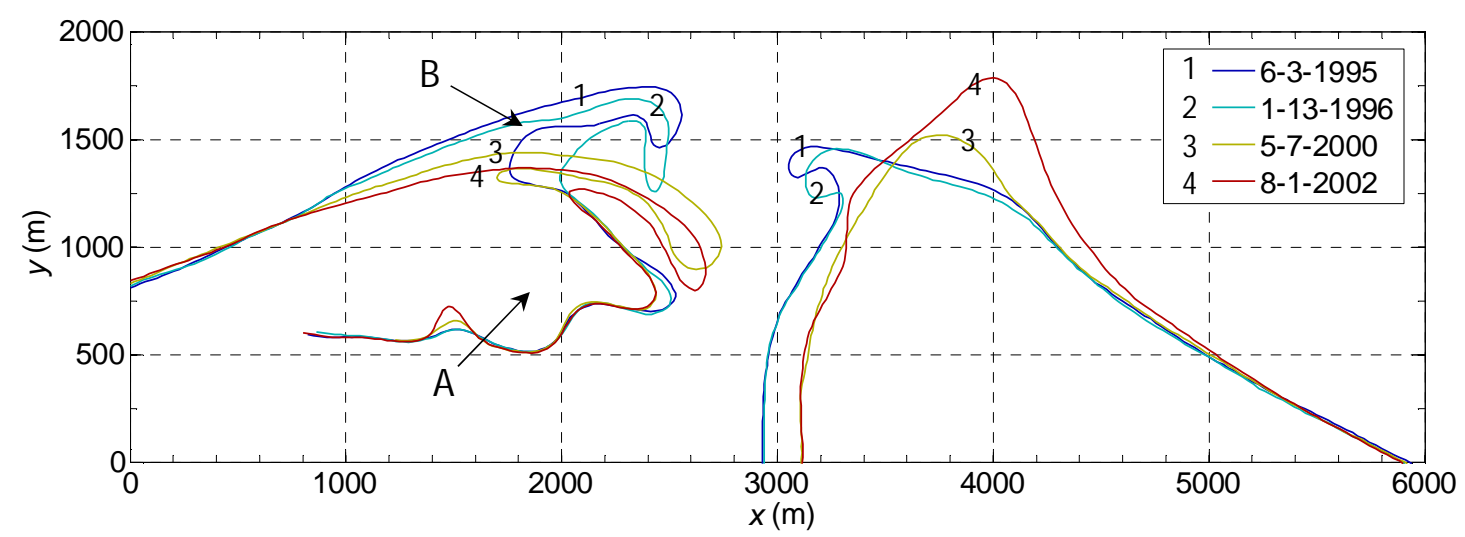

Figure 5. Detected shoreline positions of the Cua Dai River mouth in the Period 2

\section{Evolution of estuarine morphology in the Period 3 - From 2003 to 2015}

Figure 6 presents selected Landsat images of the Cua Dai River mouth in the Period 3. Some detected shoreline positions from these images are shown in Figure 7. From the beginning of this period, shoreline on the left side of the river mouth became eroded, while the cuspate shoreline on the right side of the river mouth became shorter and shifting rightwards. The retreat of shoreline on the left side has actually started since 2003; however that can be seen more clearly on the image taken in 2005 . The erosion was much more obvious on remained images. Due to this severe erosion, some resort hotels, which are located on the left side of the river mouth, constructed seawalls to protect their facilities; therefore, the protrusive part can be seen clearly in 2014 and 2015's images. Besides that, seawalls, which were constructed to protect tourist facilities, also stabilizes the shoreline on the part close to the river mouth. Illustration of this seawall will be given later in this study (Figure 13). 

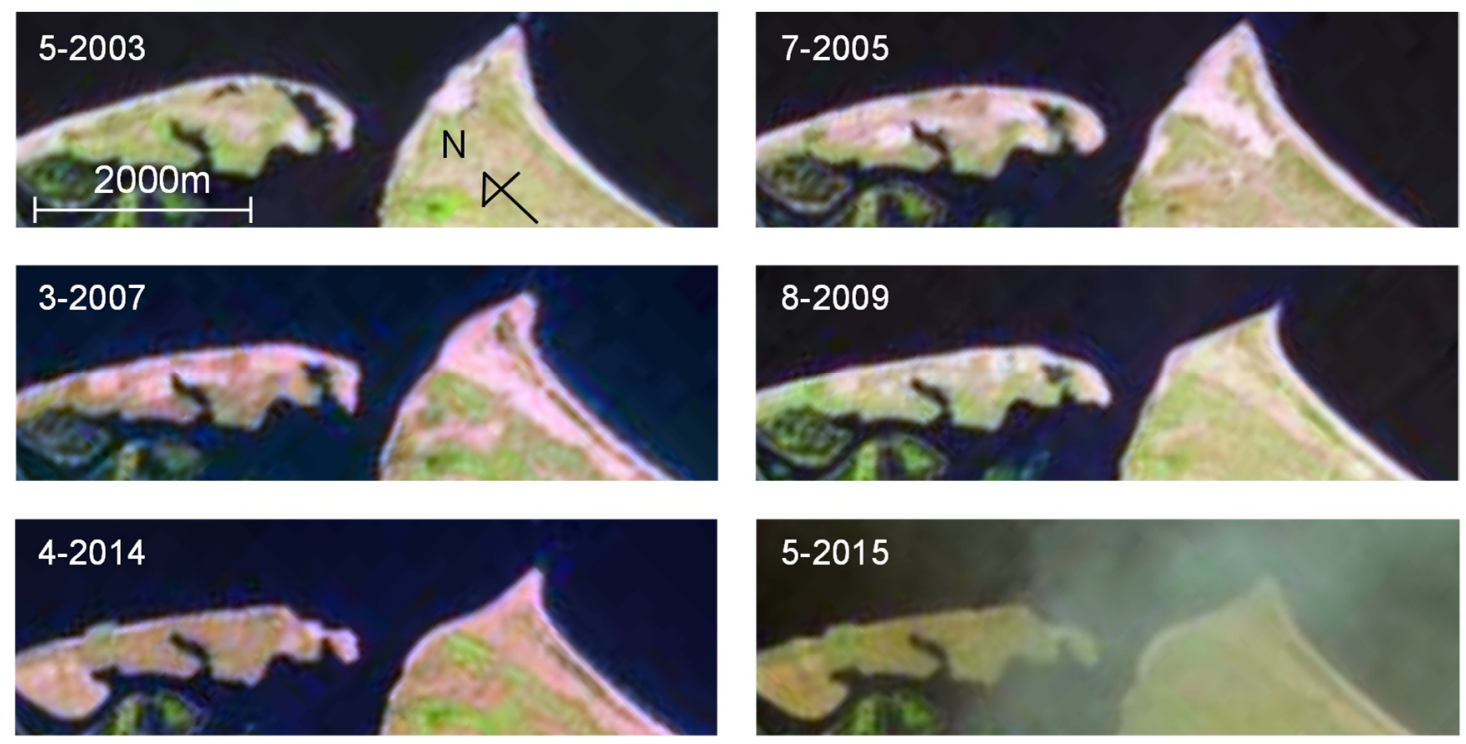

Figure 6. Satellite images of the Cua Dai River mouth in the Period 3 (USGS)

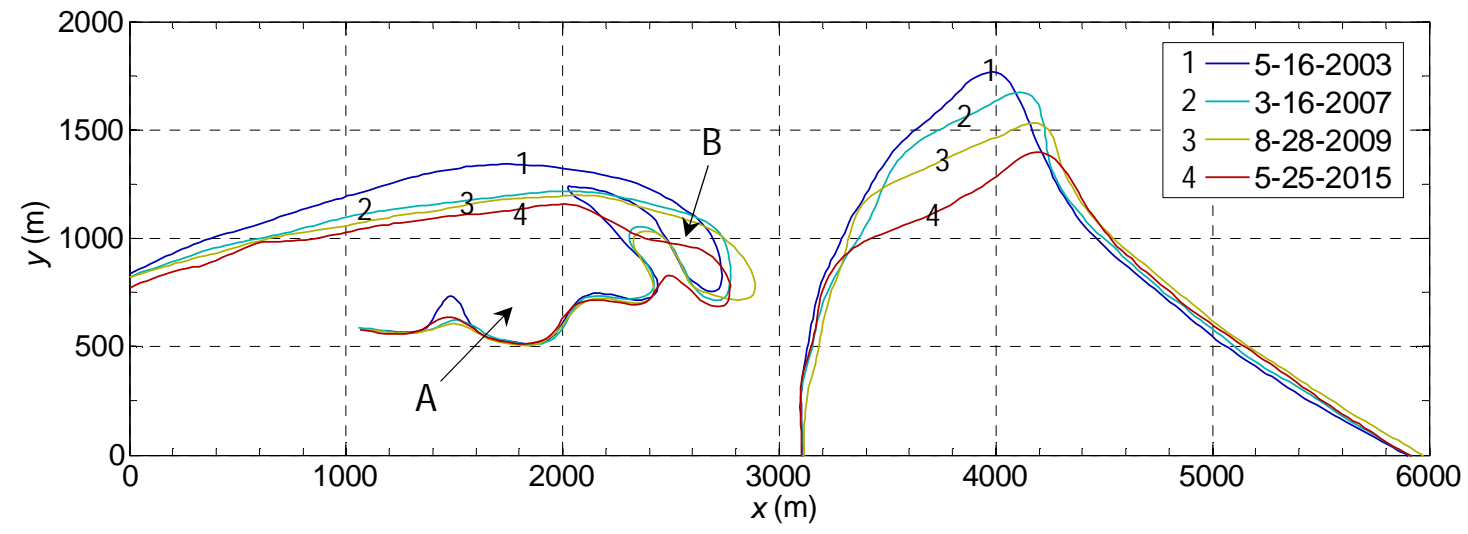

Figure 7. Detected shoreline positions of the Cua Dai River mouth in the Period 3

\section{Overall of morphological evolution at the Cua Dai River mouth in the past $\mathbf{4 0}$ years}

In order to give an overview look of morphological evolution in the past 40 years and also to reveal the distinct differences between sub-periods, selected extracted shoreline positions of sub-periods are shown in Figure 8. It can be seen clearly the advancement of shoreline position in the first period and the second, and the retreat back to the Period 1's condition in the third period. The tip of sandspit on the left side tends to shift rightwards. The position of right river bank is also recognized to be shifted rightwards. It shifted about $250 \mathrm{~m}$ in the period from 1975 to 2004; it has been stable since 2004 till 2015. The tip of cuspate shoreline on the right side of river mouth is also realized to be shifted rightwards. 


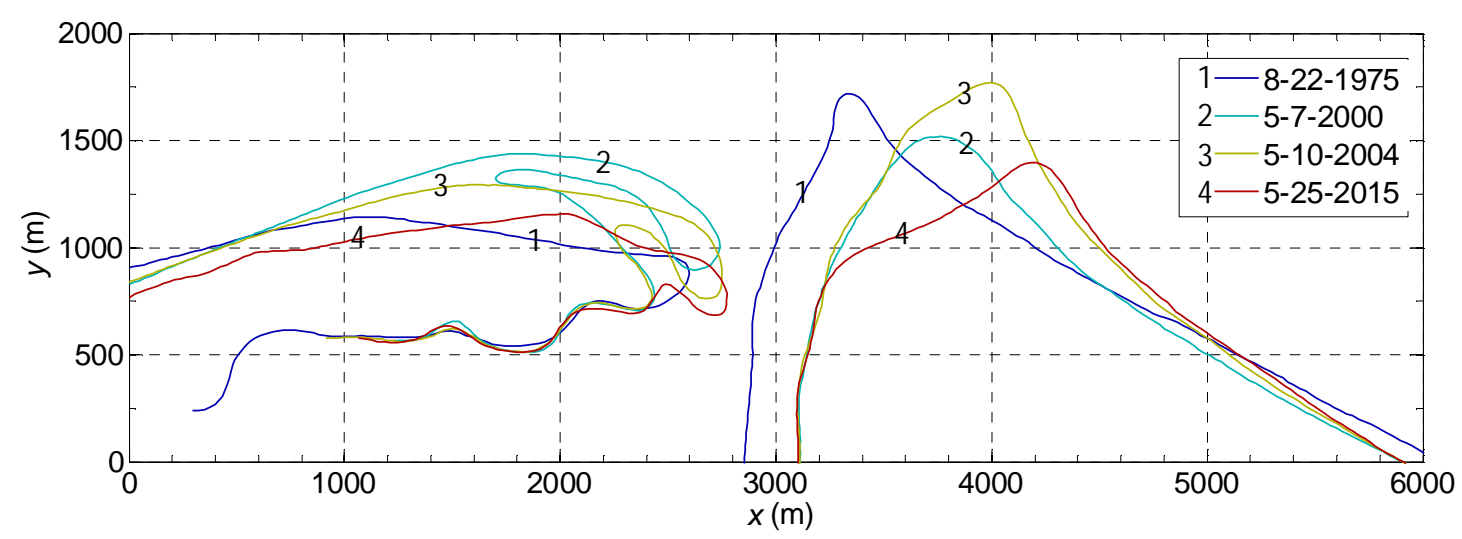

Figure 8. Evolution of shoreline positions of the Cua Dai River mouth in the past 40 years

\section{Classification of morphological type of river mouth}

As discussed above, over the past decades, the topography of the river mouth changes dramatically. It would be useful if morphology of the river mouth can be classified into typical shapes. Figure 9 shows the typical types of river mouth morphology over the past 40 years. These types are classified based the characteristics of morphology on the left and the right side of the river mouth.
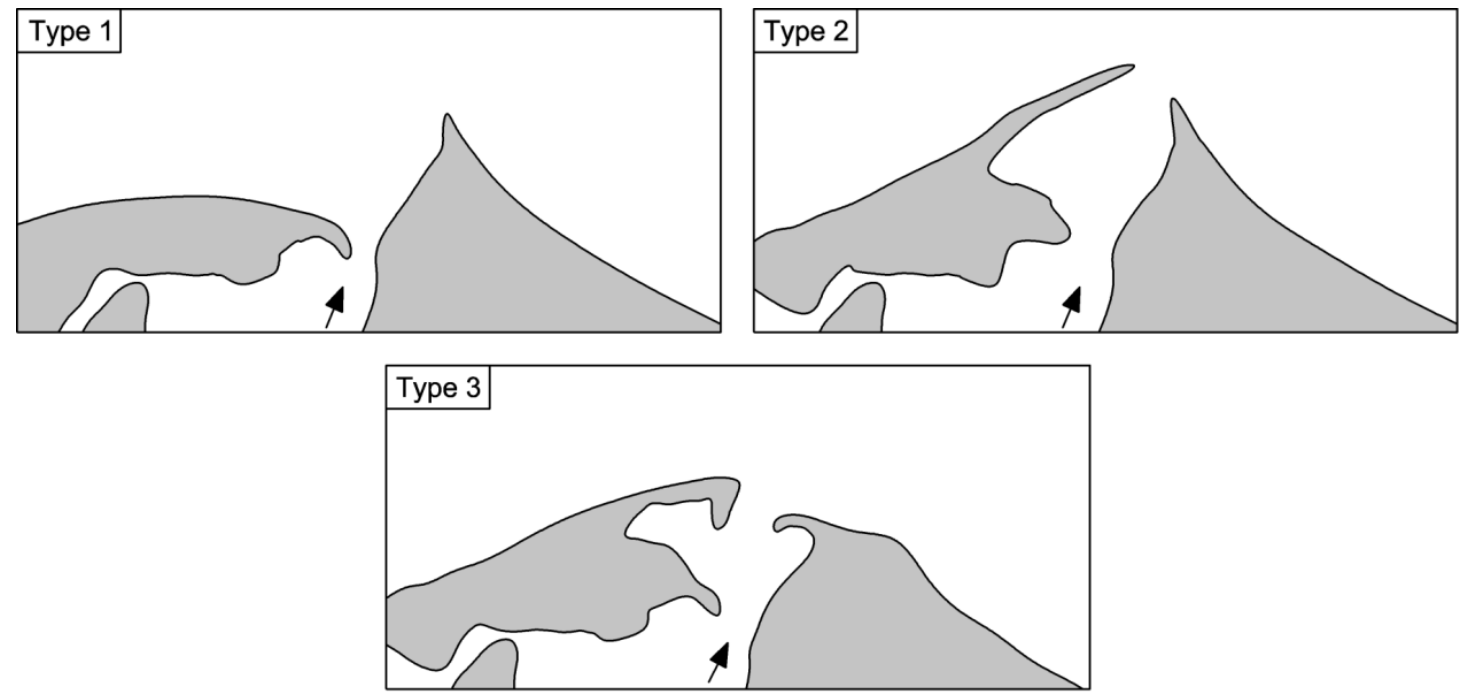

Figure 9. Classification of river mouth types in the past $\mathbf{4 0}$ years at the Cua Dai River mouth

Type 1 shows the asymmetric form of morphology on the left and the right sides. The sandspit on the left side tends to intrude into the river channel, whereas the cuspate shoreline exists on the right side. In Type 2, an extra sandspit forms on the left side after the attaching of sandbar into shoreline, and the cuspate shoreline on the right side turns to the shape of sandspit. These sandspits are long and straight; their tips towards to sea side and tends to converge each other. They makes the estuarine morphology is almost symmetry. Type 3 represents the morphology which the new sandspits on the left and right sides become shorter and tend to intrude into the river mouth. If this classification is applied to the morphology of river mouth over the past 40 years, the river mouth morphology in 1970s, late of 1980s and early of 1990s, and late of 1990s are corresponded to Types 1, 2, and 3, respectively. While from the 2000s onwards, it returns to the Type 1 again.

As discussed above, the Cua Dai River mouth has the asymmetric morphology between the left and the right sides except the time of Type 2. Especially, the right side of river mouth usually has the form of cuspate shoreline. Regarding to this kind of shoreline, Uda and Matsuda (1995) investigated the longshore sediment transport at the Omono River mouth based on bathymetric data and aerial 
photographs. They reported that the sediment of sand terrace, which formed in front of river mouth during the time of flooding, returns to the shoreline along the its outer edge resulting in cuspate shoreline. Moreover, the formation of sand terrace in front of river mouth was also experimentally studied by Tanaka and Suga (1993). Figure 10 shows the bathymetry at the river mouth in 1965, 2001 and 2014. From this data, the movement of sand terrace to south is observed clearly. Based on bathymetry data and results of satellite images analysis, there has been always cuspate shoreline (or similar shape, sandspit) on the right side. Whereas, sandspit (Sandspit B), which can be considered one of the indications of sediment movement from sand terrace, existed only in the 1980s and 1990s. In addition, an outer edge of sand terrace in Mar, 2015 is approximately estimated from satellite image and presented in Figure 13 (dotted line). In that figure, there is cuspate shoreline locating corresponding to the toe of outer edge of sand terrace on the right side, while there isn't on the left side. From above discussion, it can be said that when the sand terrace shifted to the right side of the river mouth, the sediment from the sand terrace mainly returns to shoreline on the right side. The role of sand terrace acting as sand source to maintain shoreline at the river mouth in this case is similar to the case found in Hoang et al. (2015a).

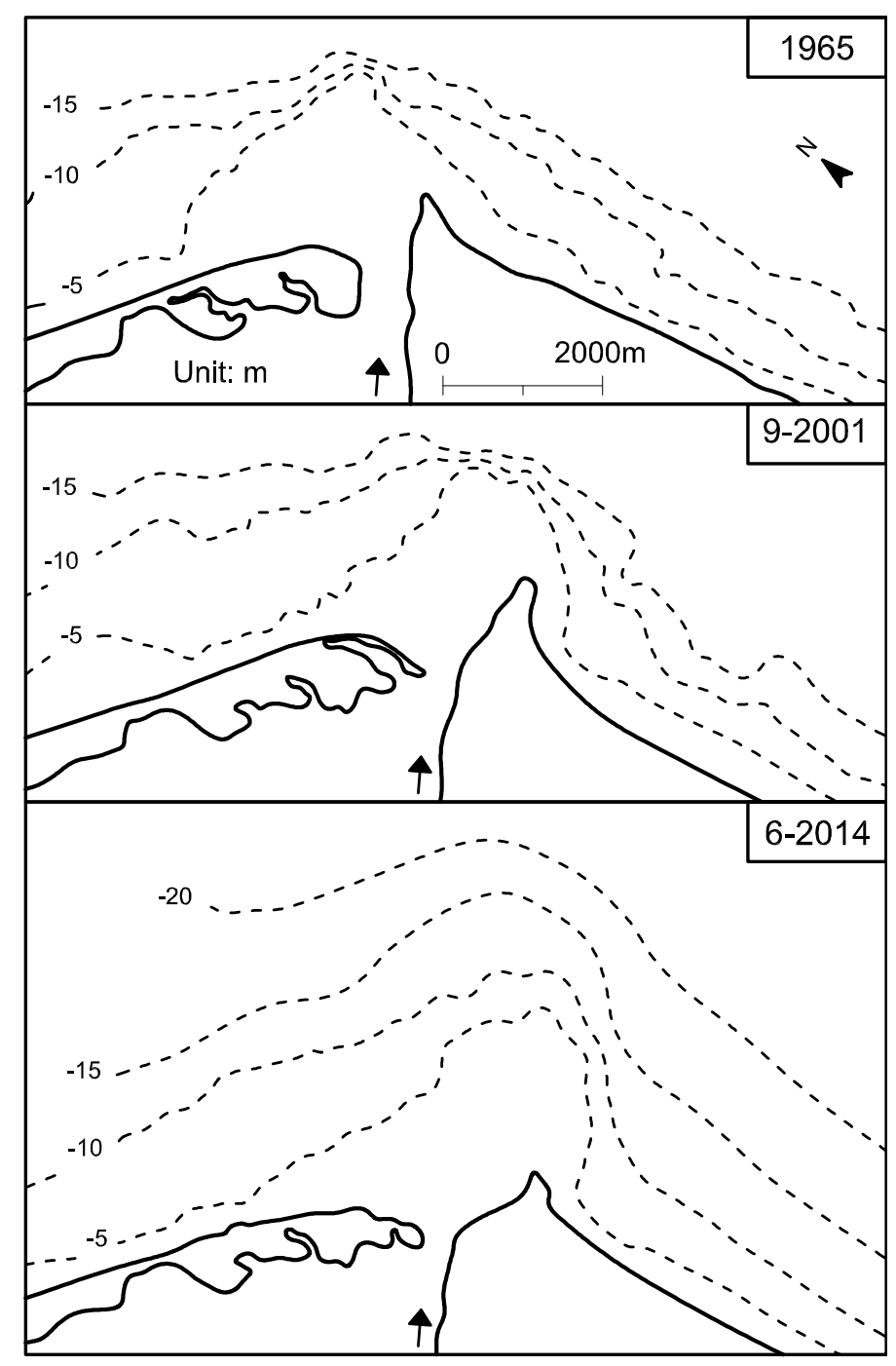

Figure 10. Bathymetric data at the Cua Dai River mouth (1965 from U.S. Army's map, 2001 and 2004 from Mau et al., 2015) 
Besides the shifting rightwards of sand terrace, similar shifting of river bank corresponding to the period of elongation to the south of the left sandspit is also recognized. Detailed investigation on features of morphological changes of the river mouth is carried out in the next part.

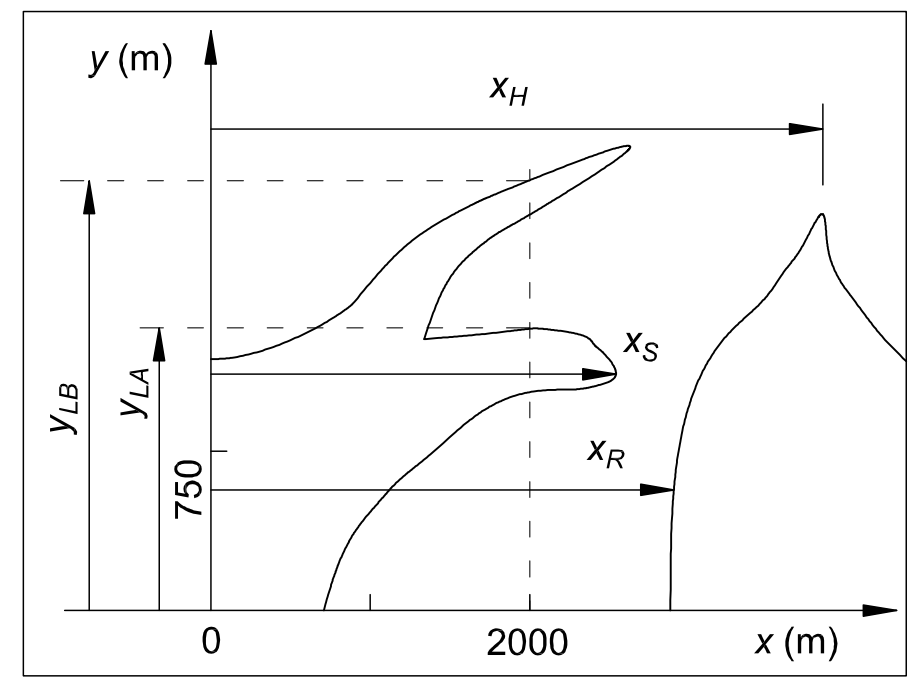

Figure 11. Schematic diagram of features of river mouth morphology

\section{Changes of morphological features of the Cua Dai River mouth}

As mentioned above, the formation of cuspate shoreline on the right of river is an important characteristic to understand the movement of sediment at the river mouth area. Hence, the temporal variation of tip of cuspate shoreline on the horizontal direction, $x_{H}$ (Figure 11), is extracted from Landsat images. These results are presented in Figure 12(a). It is recognized that the tip of cuspate shoreline have shifted greatly to the south in the period from 1996 to 2000. It fluctuated after that however the general trend shows the continuous shifting to the south but lesser magnitude. A highlighted box is attached into the graph to show the period that abrupt changes happened. Furthermore, river mouth types over the past 40 years are also added to show more details on the morphology changes and corresponded river mouth types. Besides the evolution of tip of cuspate shoreline, the evolution the bank on the right side is also investigated. The temporal variation of position of right river bank at $y=750 \mathrm{~m}, x_{R}$ (Figure 11), is shown in Figure 12(b). According to this, the right river bank was shifted significantly to the south in the period from 1996 to 2000. In the same time, the position of tip of the sandspit on the left side (Figure 12(b)) elongated to the south. According to that the shifting to the south of the right river bank has close relationship with the elongation to the south of sandspit on the left. Figure 12(c) shows the temporal variation of shoreline position at $x=2000$ m. Shoreline positions on Sandspits A and B are defined as $y_{L A}$ and $y_{L B}$ (Figure 11), respectively. The left upper line (diamond marker line) expresses the positions of shoreline during the existing of Sandspit B. Results shown in this figure indicate that the retreat of offshore sandbar creating a new sandspit and the welding of this sandspit with the existing sandspit. Since 2010, the retreat of shoreline has reached the seawall (Figure 13); hence the position of shoreline shown in Figure 12(c) was rather stable after that.

Furthermore, there is a reclaimed area which is located about $2 \mathrm{~km}$ upstream from river mouth (Figure 13). It still can be seen on the latest Google Earth image even the construction of the Cua Dai Bridge has been completed. Because of the partially trapped of river channel on the left side by this reclamation, the river flow has been being diverted rightwards. Moreover, the shifting of right river bank is also related to the development southwards of the tip of sandbank (Figure 13). The diverting of river flow to south could result in the extension of sandspit and the modification of river mouth sand terrace. In addition, not only results obtained from Landsat images analysis but also from Google Earth images (high resolution) are plotted in above three figures. According to this comparison, the results 
extracted from two types of image show very good coincidence. That indicates the reliability of Landsat images analysis in this study.

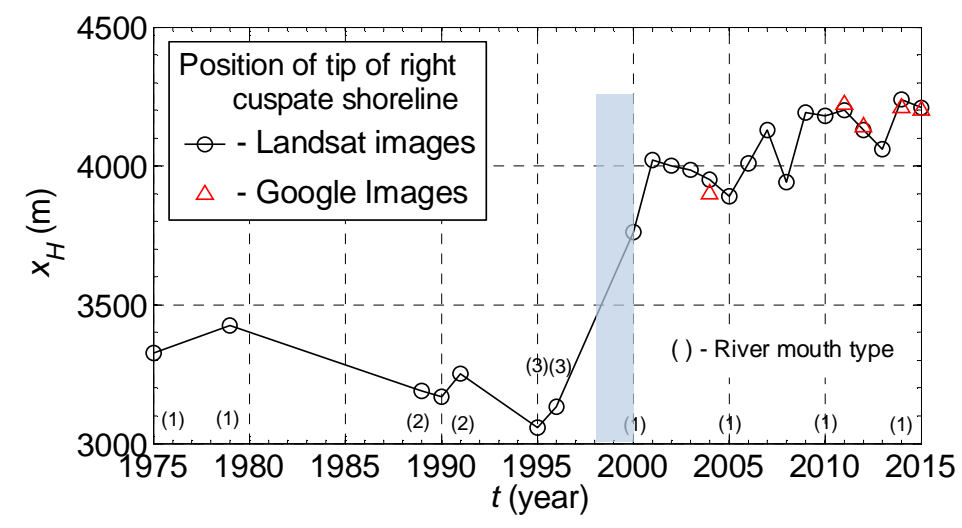

(a) Temporal variation of position of cuspate shoreline tip

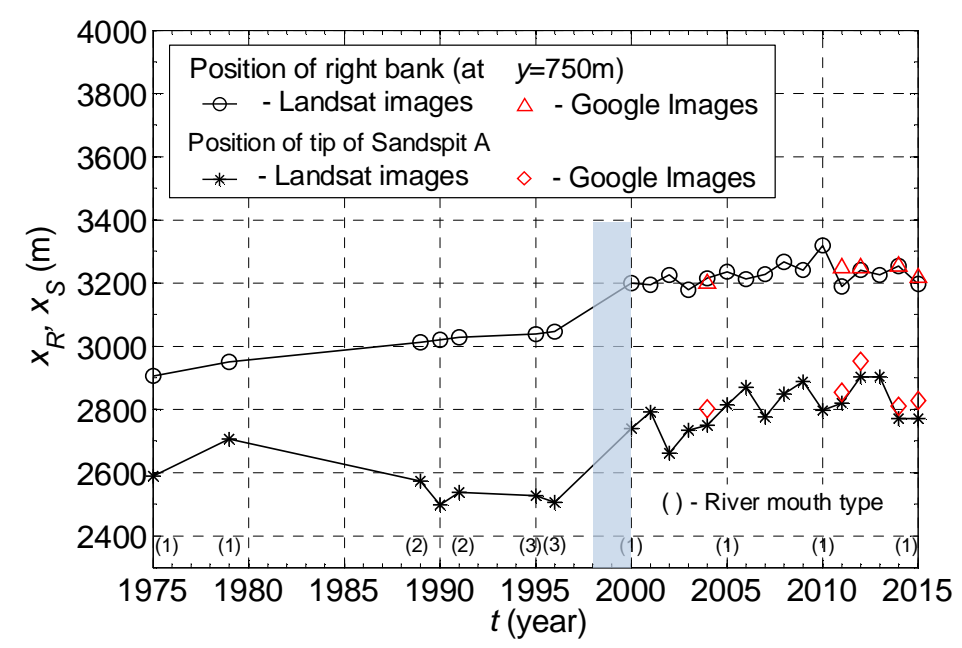

(b) Temporal variation of position of the right river bank (at $y=750 \mathrm{~m}$ ), and the tip of the left sandspit

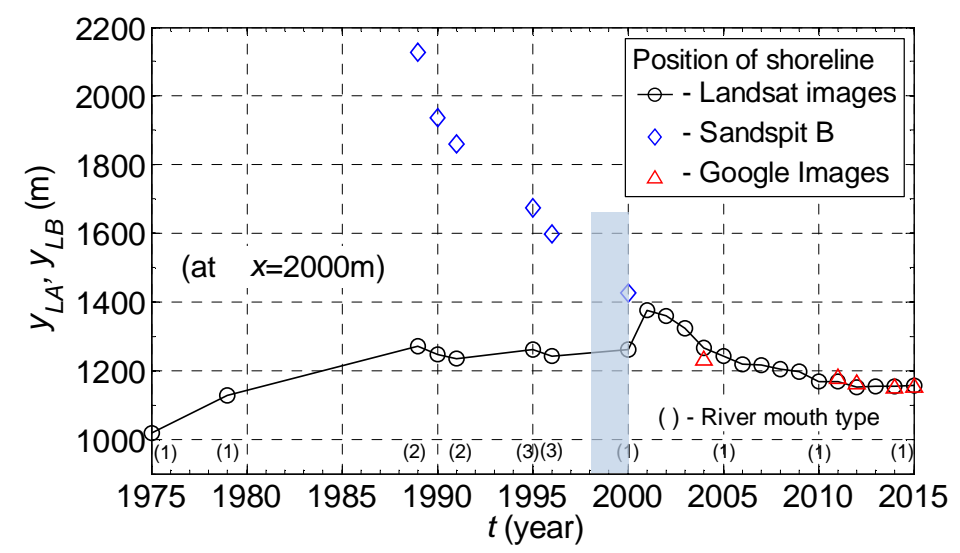

(c) Temporal variation of shoreline position on the left bank of the Cua Dai River mouth (at $x=2000 \mathrm{~m}$ )

Figure 12. Changes of the Cua Dai River mouth morphological feature (Triangular markers are data extracted from Google Earth images) 


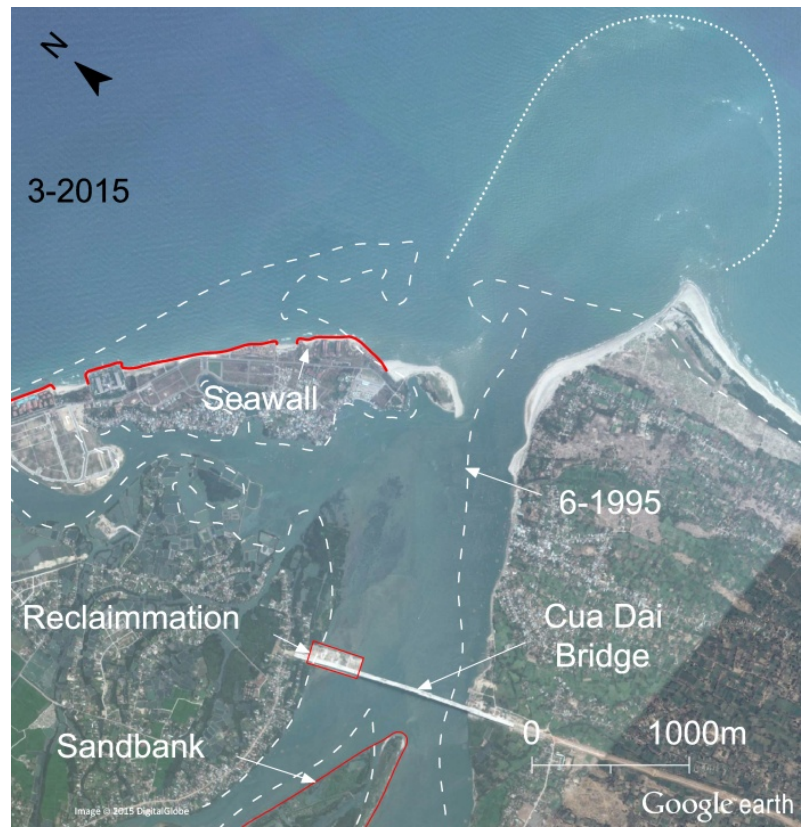

Figure 13. Reclamation in river channel and seawall along the left beach (Google Earth)

In the previous study, Viet et al. (2015), only Google Earth images were used. Based on this study, it confirms that such limited satellite cannot explain the long-term morphological evolution of the Cua Dai River mouth.

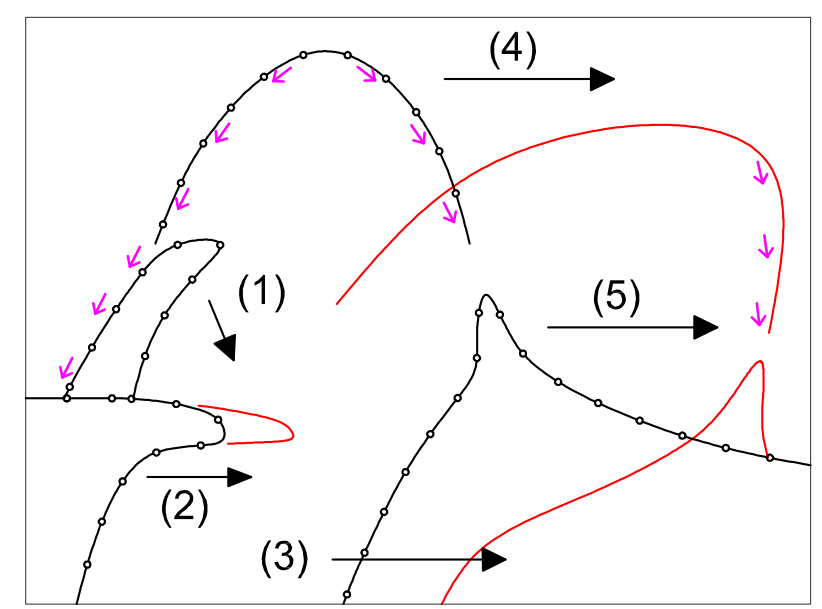

Figure 14. Schematic diagram of change of features of morphology at the Cua Dai River mouth

From above discussion, the schematic diagram, which explains the change of features of morphology at the Cua Dai River mouth, is presented in Figure 14. Arrows, which indicate the movement of sediment from sand terrace to shoreline in each case, are also included. The shifting of sand terrace to the south induced by unequal distribution of sediment from river has caused serious problems on the morphology on the left side of the river mouth. In order to redistribute the sediment to the left side as countermeasure for erosion protection, the restoration of the right river bank (as in Figure 12 (b)) to the past position by training wall can be considered. This will promote the equal sediment supply to both sides of the river mouth. Under present circumstances, in order to verifying the effectiveness of that solution, numerical simulation of river sediment discharge (e.g., Tanaka et al., 1996) can be applied. 
The development of river mouth delta is highly depended on sediment supply from river. It can be simulated by using theory of one-line model (e.g., Larson et al., 1987, Hoang et al., 2015b). In these models, the total amount of river sediment supply is assumed to distribute equally to both sides. However, as shown in this study, the difference of spilt ratio is depended on the asymmetry of the river mouth terrace. It has the temporal variation. The ratio of river sediment supply distributing to the left and the right side effects significantly to whether erosion or deposition occurs. Therefore, further study on this matter is highly required.

\section{CONCLUSIONS}

In this paper, the long-term morphological evolution of the Cua Dai River mouth was investigated. Results from the analysis of a long period Landsat images reveal the sand terrace which locates in front of the river mouth has been getting more asymmetric. The movement of sediment from the sand terrace to shoreline became south dominant resulting in more asymmetric shoreline. Severe erosion was happened to the shoreline on the north where the sediment supply was limited after the shifting south of sand terrace. In future, based on the findings in this study, by utilizing numerical simulation, more quantitative study on the erosion can be done.

\section{REFERENCES}

Duc, D.M., M.T. Nhuan, and C.V. Ngoi. 2012. An analysis of coastal erosion in the tropical rapid accretion delta of the Red River, Vietnam. Journal of Asian Earth Sciences, 43(1), 98-109.

Feyisaa, G.L., H. Meilbya, R. Fensholtb, and S.R. Proud. 2014. Automated Water Extraction Index: A new technique for surface water mapping using Landsat imagery. Remote Sensing of Environment, 140, 23-35.

Hoang, V.C., T.M. Thanh, N.T. Viet, and H. Tanaka. 2015a. Shoreline change at the Da Rang River Mouth, Vietnam. Proceedings of the $5^{\text {th }}$ International Conference on Estuaries and Coasts, 312318.

Hoang, V.C., N.T. Viet, and H. Tanaka. 2015b. Morphological change on Cua Dai Beach, Vietnam: Part II theoretical analysis. Tohoku Journal of Natural Disaster Science, 51, 87-92.

Hung, N.M., and M. Larson. (2014). Coastline and river mouth evolution in the central part of the Red River Delta, in Thao, N. D., Takagi, H. and Esteban M. (Eds), Coastal Disasters and Climate Change in Vietnam - Engineering and Planning Perspectives, Elsevier, 43-79.

Larson, M., H. Hanson, and N.C. Kraus. 1987. Analytical solutions of the one-line model of shoreline change, Technical Report CERC-87-15: U.S. Army Engineer Waterways Experiment Station.

Maiti, S. and A.K. Bhattacharya. 2009. Shoreline change analysis and its application to prediction: A remote sensing and statistics based approach. Marine Geology, 257(1-4), 11-23.

Mau, L.D. 2015. Researching on scientific bases for the protection of coasts, estuaries serving the management and sustainable development of coastal areas in Quang Nam Province (in Vietnamese).

Noshi, Y., T. Uda, A. Kobayashi, and S. Miyahara. 2015. Beach changes observed in Phan Rang City in southeast Vietnam, Proceedings of the $8^{\text {th }}$ International Conference on Asian and Pacific Coasts, Procedia Engineering, 116, 163-170.

Pardo-Pascual, J.E., J. Almonacid-Caballer, L.A. Ruiz, and J. PalomarVázquez. 2012. Automatic extraction of shorelines from Landsat $\mathrm{TM}$ and $\mathrm{ETM}^{+}$multi-temporal images with subpixel precision. Remote Sensing of Environment, 123, 1-11.

Pradjoko, E. and H. Tanaka. 2010. Aerial photograph of Sendai Coast for shoreline behavior analysis. Proceedings of the $32^{\text {nd }}$ International Conference on Coastal Engineering.

Robin, N., F. Levoy, O. Monfort, and E. Anthony. 2009. Short-term to decadal-scale onshore bar migration and shoreline changes in the vicinity of a megatidal ebb delta. Journal of Geophysical Research, 11 (F4), F04024 (13 pages).

Ryu, J.H., J.S. Won, and K.M. Min. 2002. Waterline extraction from Landsat TM data in a tidal flat: A case study in Gomso Bay, Korea. Remote Sensing of Environment, 83(3), 442-456.

Tanaka, H. and K. Suga. 1993. Sand terrace formation in front of a small river mouth due to flush flood. Advances in Hydro-Science and-Engineering, 1731-1736. 
Tanaka, H., N. Shuto, N. Kuwahara, and K. Sato. 1996. Numerical modeling of 2-D flow and sediment movement in the vicinity of Natori River mouth. Flow Modeling and Turbulence Measurements VI, 813-820.

Thanh, T.M., Y. Mitobe, V.C. Hoang, N.T. Viet, and H. Tanaka. 2015. Coastal morphology change and its relationship with climate characteristics on Nha Trang Coast, Vietnam. Proceedings of the $5^{\text {th }}$ International Conference on Estuaries and Coasts, 159-164.

Uda, T. and H. Matsuda. 1995. Interrelationship between river mouth terrace and sandspit formation at the Omono River mouth. Proceedings of Coastal Engineering, JSCE, 42, 566-570 (in Japanese).

Viet, N.T., V.C. Hoang, H.D. Hai, N.V. Giap, and H. Tanaka. 2015. Analysis on erosion of beaches adjacent to Cua Dai River mouth, central Vietnam. Proceedings of the $5^{\text {th }}$ International Conference on Estuaries and Coasts, 153-158. 